\author{
MACIEJ PTASZYŃSKI \\ https://orcid.org/0000-0003-2508-061X \\ Wydział Historii Uniwersytetu Warszawskiego
}

\title{
O KULTURZE POLEMIK RELIGIJNYCH I POWSTANIU ŚWIADOMOŚCI WYZNANIOWEJ. UWAGI NA MARGINESIE PRACY MAGDALENY LUSZCZYNSKIEJ, POLITICS OF POLEMICS. MARCIN CZECHOWIC ON THE JEWS*
}

\begin{abstract}
Abstrakt: Przedmiotem artykułu jest monografia Magdaleny Luszczynskiej poświęcona Marcinowi Czechowicowi, jednemu z najważniejszych teologów antytrynitarnych końca XVI w. Artykuł umieszcza pracę na tle dotychczasowej literatury poświęconej antytrynitarzom w Polsce oraz opracowań na temat Czechowica. Krytykując monografię za wąską podstawę źródłową i metodologiczną, proponuje nowe spojrzenie na kluczowe aspekty życia teologa. Teza artykułu głosi, że kategoria świadomości wyznaniowej pozwala inaczej ująć kwestię konwersji protestanta.
\end{abstract}

Słowa kluczowe: Marcin Czechowic, reformacja, historia Kościoła, Żydzi, świadomość wyznaniowa.
Abstract: The article deals with a monograph by Magdalena Luszczynska devoted to Marcin Czechowic, one of the most important anti-Trinitarian theologians of the late sixteenth century. The article sets the book against the backdrop of literature on the anti-Trinitarians in Poland and studies of Czechowic. While criticizing the monograph for its narrow source and methodological basis, it offers a new look at the key aspects of the theologian's life. The central thesis of the article is that the category of religious awareness allows for a different approach to this Protestant's conversion.

Keywords: Marcin Czechowic, Reformation, history of the Church, Jews, religious awareness.

* M. Luszczynska, Politics of Polemics. Marcin Czechowic on the Jews, De Gruyter Oldenbourg, Berlin-Boston 2018, ss. 180. Badania będące podstawą artykułu zostały sfinansowane ze środków Narodowego Centrum Nauki przyznanych na podstawie decyzji numer DEC-2018/31/B/HS3/00351. 
Marcin Czechowic, minister w antytrynitarnym zborze w Lublinie, należy do najważniejszych i najciekawszych protestanckich teologów w Rzeczypospolitej schyłku XVI w. Popularność duchownego przekładała się także na liczne ataki adwersarzy, często nieprzebierających w oskarżeniach. Marcin Łaszcz rozwodził się nad tym, że

Confessya Nowokrzczeńcow przywędrowała do Polski z Czechowiczem. Ten będąc klechą i dzwonnikiem, został Ministrem Confessyey Luterskiey, potym Kalwinowey, ale posłany od zboru do Genewy, aby się w niektórych Artykułach Bezy Superintendenta Francuskiego poradził, wstąpił na drodze do iednego Ministra Nowokrzczeńca, od którego tey Confessyey przewyknął, y do Polski przyiachawszy, w Kuiawach naprzod przewierzgnął do siebie Niemoiewskiego y inaszych, potym Zbor pod mury Lubelskimi założyli, około roku $1563^{1}$.

W tych polemicznych uwagach prawda splata się nierozerwalnie z fałszem. Jak wykazał w swojej przełomowej monografii Lech Szczucki, ani Czechowic nie był pierwszym antytrynitarzem czy anabaptystą, ani nie odwiedził Teodora Bezy, ani zapewne nie spotkał się po drodze $\mathrm{z}$ anabaptystami na Morawach ${ }^{2}$. Głównym oskarżeniem w wywodach katolickiego oponenta jest jednak niestałość Czechowica, porzucającego najpierw katolicyzm na rzecz luteranizmu, potem luteranizm dla kalwinizmu, a ostatecznie kalwinizm - dla anabaptyzmu. Trzykrotna zmiana wyznania była egzemplifikacją zarzutu nieustannie powracającego w katolickich polemikach z protestantyzmem: zakwestionowanie części średniowiecznej tradycji i roli stolicy Piotrowej oznaczało relatywizm i absolutną dowolność 3 .

Czechowic był wówczas głównym przeciwnikiem jezuitów, kalwinistów oraz luteranów. Urodzony w 1532 r. przyszły teolog zapewne wychowany był w tradycyjnym katolicyzmie. Na pozycje protestanckie przeszedł dopiero jako młodzieniec lub dorosły mężczyzna, być może podczas

${ }^{1}$ M. Łaszcz, Okulary na Zwierciadlo nabozenstwa chrześcianskiego w Polszcze. Poczawszy od przystania Polakow na wiarę Chrześciańska, aż do teraźnieyszego Roku 1594, Wilno 1594, k. J1v.-J2r.

${ }^{2}$ L. Szczucki, Marcin Czechowic (1532-1613). Studium z dziejów antytrynitaryzmu polskiego XVI wieku, Warszawa 1964, s. 38, przyp. 83, s. 231-232; por. S. Kot, Czechowic Marcin, PSB, t. 4, Kraków 1938, s. 306-309.

${ }^{3}$ Wiele elementów tej krytyki można odnaleźć w pracach współczesnych historyków, zob. B. Gregory, Niezamierzona reformacja. Od rewolucji religijnej do świeckiego społeczeństwa, [w druku] (oryg. ang. 2012). Na temat zaangażowanej konfesyjnie publicystyki zob. J. Sojka, Luter jako arcyheretyk i rewolucjonista - powrót XVI-wiecznej antyreformacyjnej polemiki w polskiej debacie w roku jubileuszu 500 lat reformacji, w: Marcin Luter 1517-2017, red. K. Obremski, Toruń 2018, s. 113-134. 
edukacji w Poznaniu ok. 1543/1544 r. lub podczas studiów w Lipsku dziesięć lat później. Jak ustalił Szczucki, aktywność Czechowica jest uchwytna w źródłach dopiero od momentu zadzierzgnięcia więzów z Mikołajem Radziwiłłem Czarnym około 1558 r. ${ }^{4}$ Wówczas młody człowiek znalazł się w samym centrum dziejów polskiej i litewskiej reformacji, wkraczającej w nową fazę po powrocie do Polski Jana Łaskiego w 1556 r. Przybycie wielkiego teologa, przyjaciela i zwolennika myśli Jana Kalwina wpłynęło na przyspieszenie procesów tworzenia się nowych wyznań protestanckich i organizacji Kościołów. Przede wszystkim zaś - na opowiedzenie się zborów małopolskich i litewskich po stronie ewangelicyzmu reformowanego w jego kalwińskim wydaniu ${ }^{5}$. Wkrótce jednak w Małopolsce i na Litwie zaczęły pojawiać się coraz liczniejsze głosy kwestionujące tradycyjną naukę o Trójcy, a wyrażane donośnie i odważnie w obliczu śmierci Łaskiego w 1560 r. Stronnictwo antytrynitarzy zyskało wówczas protektora w osobie Mikołaja Radziwiłła Czarnego, w którego kręgu znajdował się zapewne od 1559 r. również Czechowic ${ }^{6}$ Z polecenia możnego patrona Czechowic został wysłany do Szwajcarii z pakietem listów do reformatorów helweckich, a wrócił stamtąd z całą wiązką korespondencji dla magnatów i teologów działających w państwie polsko-litewskim. Po powrocie teolog zaangażował się w życie zborowe, aktywnie uczestnicząc w synodach protestanckich i coraz częściej sięgając po pióro. Po śmierci Czarnego duchowny opuścił Litwę, udając się na Kujawy, a następnie w 1570 r. osiadając w Lublinie, gdzie stworzył swoje najważniejsze prace oraz brał udział w dysputach z jezuitami.

Ze względu na bogatą i ciekawą spuściznę jego postać i poglądy nieustannie powracały na kartach wybitnych badaczy antytrynitaryzmu w XIX i XX w.: Konrada Górskiego, Alodii Kaweckiej-Gryczowej, Stanisława Kota, Zbigniewa Ogonowskiego, Janusza Tazbira, Marka Wajsbluma oraz Lecha Szczuckiego, który poświęcił Czechowicowi zwięzłą, acz bardzo głęboką monografię. W pracach tych badaczy niezwykle szczegółowo opisano genezę i losy wspólnoty antytrynitarskiej, określającej się często mianem braci polskich (Fratres Poloni) lub Kościoła mniejszego (Ecclesia minor lub Ecclesia reformata minor), a także rekonstruowano poglądy najważniejszych myślicieli. Zarówno studia powstałe przed 1945 r., jak

${ }^{4}$ L. Szczucki, op. cit., s. 15. Przedstawiona poniżej rekonstrukcja dziejów protestantyzmu i roli Czechowica zaczerpnięta jest z pracy Szczuckiego.

${ }^{5}$ Zob. H. Kowalska, Działalność reformatorska Jana Łaskiego w Polsce 1556-1560, Warszawa 1999.

${ }^{6}$ Ten aspekt działalności Czarnego bardzo dobrze ukazano w: J. Jasnowski, Mikołaj Czarny Radziwiłł (1515-1565). Kanclerz i marszałek ziemski Wielkiego Księstwa Litewskiego, wojewoda wileński, Warszawa 1939. 
i w okresie PRL imponują szerokim spojrzeniem i bardzo wielostronnym ujęciem omawianych zagadnieńn ${ }^{7}$. Wiele $\mathrm{z}$ tych prac miało interdyscyplinarny charakter, łącząc historię filozofii z historią społeczną, a także będąc oryginalnym, choć marginalnym, wkładem do dorobku tzw. warszawskiej szkoły historii idei ${ }^{8}$. Interdyscyplinarność tych studiów, łączących wiele warsztatów humanistyki, do dziś stanowi wzór do naśladowania, choć nieraz może nawet zaskakiwać. Prace renomowanych historyków filozofii często koncentrują się bowiem w dużym stopniu na precyzyjnej i szczegółowej rekonstrukcji historycznych wydarzeń, zaniedbując lub spychając na drugi plan teologiczną treść sporów. Dorobek tych studiów podsumował w swojej ostatniej rozprawie Ogonowski ${ }^{9}$, a wykorzystał w badaniach nad teologią socyniańską Kęstutis Daugirdas ${ }^{10}$. Bardzo syntetycznie omówił te prace Piotr Wilczek w esejach historiograficznych, nie wnosząc jednak nowych treści ani interpretacji ${ }^{11}$. Wydany przez tego badacza oraz Michała Choptianego tom Antytrynitaryzm w Pierwszej Rzeczypospolitej w kontekście europejskim - wbrew tytułowi - dotyczy natomiast w bardzo niewielkim stopniu antytrynitaryzmu w Rzeczypospolitej i abstrahuje niemal całkowicie od dorobku dotychczasowych polskich badaczy tego zagadnienia ${ }^{12}$.

Bogata twórczość - bardziej niż sama postać - Marcina Czechowica w ostatnich latach budzi zainteresowanie przede wszystkim literaturoznawców, językoznawców i biblistów. Polemiki Czechowica z jezuitami były omawiane przez Piotra Wilczka i Pawła Ciechana ${ }^{13}$. Na twórczość

${ }^{7}$ Inna ocena dorobku tej historiografii w: J. Żukowski, Sąd nad arianami w kieleckim Pałacu Biskupów Krakowskich, Kielce 2018, s. 61-80. Autor sięga do popularnonaukowych prac wspomnianych badaczy, cytując przede wszystkim ustępy o zabarwieniu ideologicznym, służące obronie postawy i działań braci polskich, zob. np. s. 77: „Badacze pokroju przywołanego Urbana czy Tazbira [--] tłumaczyli postawę większości braci polskich niezrozumieniem sytuacji historycznej”. Uwaga o „pokroju” ma sugerować głęboką ideologizację tych prac i jednostronność ocen.

${ }^{8}$ Znamienne, że głosu tego zabrakło w: Warszawska szkoła historii idei. Tożsamość, tradycja, obecność, red. P. Grad, Warszawa 2014.

9 Z. Ogonowski, Socynianizm. Dzieje, poglady, oddziaływanie, Warszawa 2015.

${ }^{10}$ K. Daugirdas, Die Anfänge des Sozinianismus. Genese und Eindringen des historischethischen Religionsmodells in den universitären Diskurs der Evangelischen in Europa, Göttingen 2016, s. 35-39 (na temat dorobku polskich badań nad socynianizmem).

${ }^{11}$ P. Wilczek, Polonia reformata. Essays on the Polish reformation(s), Göttingen 2016, s. 36-45.

12 Antytrynitaryzm w Pierwszej Rzeczypospolitej w kontekście europejskim. Źródła - rozwój - oddziaływanie, red. M. Choptiany, P. Wilczek, Warszawa 2017; zob. omówienie M. Ptaszyńskiego w: OiRP 62, 2018, s. 230-234.

13 P. Wilczek, Wyobraźnia. Polemiki Marcina Łaszcza z Marcinem Czechowicem, w: idem, Dyskurs - przekład - interpretacja. Literatura staropolska i jej trwanie we wspótczesnej 
samego Czechowica z pespektywy językoznawczej spojrzała Magdalena Hawrysz ${ }^{14}$. Przekładom Nowego Testamentu, ogłoszonym przez Czechowica w 1577 oraz 1594 r., poświęcili obszerne studia Katarzyna Meller, Rajmund Pietkiewicz i Izabela Winiarska-Górska ${ }^{15}$. Zupełnie nieudaną pracą była natomiast rozprawa Jerzego Kolarzowskiego poświęcona myśli socyniańskiej ${ }^{16}$.

Na ustaleniach tych badaczy ufundowana jest praca doktorska Magdaleny Luszczynskiej, obroniona na Hebrajskim Uniwersytecie w Jerozolimie. Przedmiotem analizy badaczki nie są jednak wszystkie pisma Czechowica, lecz wyłącznie jeden utwór (Odpis Jakoba Żyda, Kraków 1581) oraz fragment wydanych w 1575 r. Rozmów chrystyjanskich, który ich autor określił Gadkami żydowskimi. Centralnym zagadnieniem pracy, którą Autorka zalicza do gatunku historii kultury oraz mikrohistorii, jest pytanie o stosunek antytrynitarzy do Żydów w świetle tych pism Czechowica, odczytywanych na szerszym tle polemik religijnych tego okresu.

Praca ma przejrzystą konstrukcję: prócz wstępu i zakończenia składa się z pięciu rozdziałów, z których dwa były już wcześniej publikowane, o czym Autorka informuje w przedmowie oraz w przypisach. Każdy z rozdziałów stanowi analityczne studium odpowiadające na inne pytanie badawcze. W pierwszym rozdziale Luszczynska analizuje stosunek do Żydów w pierwszych polemikach antytrynitarzy; w drugim - przedmiotem zainteresowana są Gadki żydowskie; w trzecim - Odpis Jakoba Żyda; w czwartym - źródła wiedzy Czechowica na temat Żydów. W piątym rozdziale Autorka zastanawia się natomiast nad obrazem własnym Czechowica w owych polemikach. Trudno nie dostrzec, że ten katalog

kulturze, Katowice 2001, s. 115-127; P. Ciechan, Obraz jezuitów w Zwierściadłku panienek chrystyjańskich Marcina Czechowica, „Wschodni Rocznik Humanistyczny” 9, 2013, s. 31-41.

${ }^{14}$ M. Hawrysz, Polemiczna twórczość Marcina Czechowica w perspektywie genologii lingwistycznej, Zielona Góra 2012; eadem, XVI-wieczny dyskurs polemiczny w świetle pism Grzegorza Pawła z Brzezin, „Poznańskie Studia Polonistyczne. Seria Językoznawcza” 25 (45), 2018, s. 45-59.

${ }^{15}$ K. Meller, Słowa jak ziarna. Reformacyjne idee, książki, spory, Poznań 2012, s. 179201; R. Pietkiewicz, Biblia Polonorum. Historia Biblii w języku polskim, t. 1: Od początku do 1638 roku, Poznań 2016, s. 440-452; idem, Polskie antytrynitarskie przekłady Biblii $w$ dialogu Pierwszej Rzeczypospolitej ze wschodnia i zachodnia Europa, w: Antytrynitaryzm w pierwszej Rzeczypospolitej, s. 262-286; I. Winiarska-Górska, Ideologia unitariańska a strategie translatorskie i styl przekładu Nowego Testamentu Marcina Czechowica (1577), „Poznańskie Studia Polonistyczne. Seria Językoznawcza" 25 (45), 2018, s. 277-313; zob. także eadem, Szesnastowieczne przekłady Pisma Świętego na język polski (1551-1599) jako gatunek nowożytnej ksiązki formacyjnej, Warszawa 2017.

16 Zob. M. Ptaszyński, rec.: J.J. Kolarzowski, Idea praw jednostki w pismach braci polskich. U narodzin nowożytnej koncepcji praw człowieka, Warszawa 2009, OiRP 56, 2012, s. 261-272. 
pytań nie ma systematycznego charakteru i praca stanowi raczej zbiór analitycznych studiów na temat kilku wybranych aspektów dwóch utworów bardzo płodnego i znaczącego pisarza okresu reformacji. Z pewnym zdziwieniem należy podkreślić, że mimo iż podstawowe dzieło Czechowica, Rozmowy chrystyjańskie, doczekało się znakomitej edycji ${ }^{17}$, Autorka korzystała tylko ze starego druku. W bibliografii natomiast, która wraz z indeksem osób zamyka pracę, wbrew utartemu zwyczajowi nie oddzielono źródeł od opracowań. Wśród tych ostatnich znajdują się więc staropolskie edycje dzieł Czechowica, z wyjątkiem traktatu Zwierściadłko panienek chrystyjańskich, który zacytowano za edycją Katarzyny Meller i Dariusza Chemperka ${ }^{18}$.

Najważniejsze ustalenia przedstawione w monografii dotyczą postrzegania i wykorzystania judaizmu w dziełach antytrynitarzy w Polsce. Analiza wybranych pism Grzegorza Pawła z Brzezin, Piotra z Goniądza i Szymona Budnego prowadzi Autorkę do wniosku, że w oskarżeniach o powtarzanie „błędów żydowskich” nie było żadnej stałości („lack of consistency”, s. 40) wśród antytrynitarnych teologów. Właściwie każda różnica poglądów mogła dać asumpt do formułowania takich zarzutów (zob. s. 30). Autorka zapewne słusznie dopatruje się ich nawet w miejscach, gdzie nie padało określenie „Żyd” lub „żydowski”, ale polemiści krytykowali przeciwników za zbyt literalne rozumienie Pisma lub zaślepienie na wymiar duchowy chrześcijaństwa (s. 36). Ten stereotypowy obraz Żyda we wczesnych polemikach skłania Autorkę do wniosku, że teolodzy antytrynitarni nie interesowali się społecznością żydowską, a figurę Żyda wykorzystywali tylko jako swoisty zabieg retoryczny (s. 41).

Wniosek ten służy z pewnością jako dobry wstęp do rozważań na temat pism Czechowica, który najwięcej i najgłębiej pisał o kulturze żydowskiej, zarazem jednak trzeba przyznać, że konkluzja ta oparta jest na bardzo chwiejnych podstawach. Z bogatej twórczości polemicznej antytrynitarzy Autorka wybrała bowiem tylko trzech autorów, których myśl analizowała każdorazowo na przykładzie jednego pisma, nie uwzględniając kontekstu jego powstania. Również z monumentalnego dzieła Czechowica Rozmowy chrystyjańskie Autorka wybiera tylko środkowe partie, zwane Gadkami żydowskimi, gdzie lubelski teolog explicite mierzy się z dziedzictwem judaizmu. Wbrew utartej interpretacji Rozmów

${ }^{17}$ M. Czechowic, Rozmowy chrystyjańskie, oprac. A. Linda, M. Maciejewska, L. Szczucki, Z. Zawadzki, Warszawa, Łódź 1979.

${ }_{18}$ M. Czechowic, Zwierściadłko panienek chrystyjańskich, oprac. K. Meller, D. Chemperek, Warszawa 2010. 
Autorka słusznie zauważa, że nie są one w gruncie rzeczy utworem katechetycznym, lecz stricte polemicznym (s. 56). Figura Żyda i judaizmu była - podobnie jak w pismach innych antytrynitarzy - bardzo stereotypowa, a jej znaczenie polegało na stworzeniu „polemicznego Innego" (,polemical «Other»”, s. 57), niezbędnego do wykrystalizowania własnej tożsamości antytrynitarzy.

W dalszej partii książki Autorka zestawia Gadki żydowskie z dziełem Odpis Jakoba Żyda, analizując wybrane wątki sporu między mistrzem a uczniem oraz Żydem Jakubem: kontrowersje wokół kategorii narodu wybranego, hermeneutyki biblijnej, Talmudu, szabasu czy obrzezania. Generalnie Autorka sceptycznie odnosi się do deklarowanych kompetencji językowych teologa. Krytykując Biblię nieświeską, Czechowic przyznawał bowiem, że posługiwał się najchętniej Biblią brzeską, a nie którąś z wielojęzycznych edycji oryginalnych tekstów biblijnych. Także Czechowica znajomość literatury talmudycznej była - wedle Autorki niezwykle ograniczona. Wnioski te są oczywiście ciekawe i słuszne, ale trzeba zauważyć, że hipotezy te powinny zostać potwierdzone analizami biblijnych przekładów ogłoszonych przez Czechowica.

Podobnie jak poprzednicy, Autorka uważa, że za polemiką z judaizmem w gruncie rzeczy kryje się spór z innymi wyznaniami chrześcijańskimi (s. 106, 113), choć głębokie zainteresowanie kulturą żydowską stawia Czechowica w awangardzie etnografii w Polsce (,an avant-garde representative of polemical ethnography tendency in Poland", s. 130). W zakończeniu pracy Autorka wróciła do pytania o wątki biograficzne w omawianych utworach Czechowica, zwracając uwagę na stylizację Czechowica-Nauczyciela w Rozmowach, służących także zbudowaniu i umocnieniu pozycji teologa w obrębie społeczności antytrynitarnej (s. 151, 162).

Wnioski Autorki poparte są obszernymi cytatami z dzieł Czechowica, choć analizy często ograniczają się do eksplikacji sensu (czasami dość zawiłego i wyrażonego trudnym językiem) wywodu teologa. Wątpliwości budzą natomiast odwołania do historycznego kontekstu, który jest w gruncie rzeczy bardzo słabo zarysowany, mimo że Autorka kilkakrotnie zastrzega, iż praca jest dziełem historycznym (s. 16, 26). Z pełną świadomością, że chodzi tu o wątki dla wywodu Autorki marginalne, warto je jednak krótko poruszyć, zwracając uwagę na kwestie kształtowania się wyznań oraz tożsamości konfesyjnych.

Za błędną trzeba uznać decyzję Autorki, aby określać antytrynitarzy mianem „arian”. Jego użycie ma już co prawda ogromną tradycję w historiografii, ale przemiany ostatnich lat, zwłaszcza zwiększenie się wrażliwości społecznej na konotacje wielu pozornie deskryptywnych terminów, powinny znaleźć odzwierciedlenie także w warsztacie badaczy. 
Autorka zdaje sobie oczywiście sprawę, że jest to epitet polemiczny, a właściwe wyzwisko stosowane przez przeciwników, aby zdyskredytować teologów podważających tradycyjny dogmat trynitarny (zob. s. 4, przyp. 14; s. 141). Określenie nie tylko sugeruje, że antytrynitarze powielali błędy zwalczone już przez Kościół w starożytności, ale także - że byli zorganizowaną grupą o homogenicznych poglądach. Było to dalekie od prawdy i aby to wykazać, warto się chwilę zatrzymać przy pytaniu o strukturę Kościołów i stan teologii.

W pierwszych zdaniach pracy, Autorka usiłuje umieścić historię antytrynitaryzmu na szerokim tle dziejów reformacji: „Gdy w 1517 r. Marcin Luter napisał swoje 95 tez na temat mocy odpustów [--], nie mógł przypuszczać, że rozpoczął rewolucję religijną. [--] W ciągu niecałych trzech dekad nowe denominacje, które stały się znane jako luteranizm i kalwinizm, zyskały uznanie jako oficjalne kościoły państwowe w wielu częściach Zachodniej Europy"19. Rozpoczęcie narracji o reformacji od przybicia tez jest krokiem bezpiecznym, a nawet nieco sztampowym, ale już uznanie, że niecałe trzydzieści lat później luteranizm i kalwinizm istniały w postaci „Kościołów państwowych” czy „krajowych” w wielu regionach Europy, jest fałszywe na wielu poziomach. Poglądy głoszone przez Marcina Lutra, jego współpracowników w Wittenberdze i szybko powiększające się grono teologów faktycznie od połowy lat dwudziestych były stopniowo przyjmowane w coraz liczniejszych terytoriach Rzeszy, a następnie w Skandynawii. Elementem spajającym tę luźną grupę było początkowo kilka symbolicznych kwestii i przywiązanie do osoby Lutra, a nie systematyczna wykładania poglądów, którą dopiero w $1530 \mathrm{r}$. przedłożono na sejmie Rzeszy w formie Wyznania augsburskiego. Wedle współczesnych badaczy, tożsamość konfesyjna luteranów - skupiona wokół poglądów, a nie osoby Lutra - wykształciła się dopiero w latach czterdziestych, a wykuła ostatecznie $\mathrm{w}$ toku bojów przeciw interim augsburskiemu, narzuconemu przez cesarza w $1548 \mathrm{r}^{20}$

19 „When in 1517 Martin Luther wrote his Ninety-Five Theses on the Power of Indulgence [--] he could not have expected that he began a religious revolution. [--] In less than three decades, new Christian denominations that came to be known as Lutheranism and Calvinism were recognised as official state Churches in many regions of Western Europe", s. 1.

${ }^{20}$ I. Dingel, Wie lutherisch war die Wittenberger Reformation. Von konfessioneller Vielfalt $z u$ theologischer Profilierung, w: Initia Reformationis. Wittenberg und die frühe Reformation, red. I. Dingel, A. Kohle. S. Rhein, E.-J. Waschke, Leipzig 2017, s. 416-422, tu: 422-427; A. Beutel, „Wir Lutherischen”. Zur Ausbildung eines konfessionellen Identitätsbewusstseins bei Martin Luther, „Zeitschrift für Theologie und Kirche” 110, 2013, s. 164-17; V. Leppin, Wie reformatorisch war die Reformation? „Zeitschrift für Theologie und Kirche” 99, 
W momencie, gdy Luter ogłaszał tezy, kalwinizm jeszcze nie istniał: należy przypomnieć, że Jan Kalwin (ur. 1509) był o pokolenie młodszy od Lutra (ur. 1483) i dopiero dwie dekady po przybiciu tez opowiedział się otwarcie po stronie protestantyzmu ${ }^{21}$. Korzenie tradycji ewangelicyzmu reformowanego tkwią co prawda w działalności Ulricha Zwingliego w Zurychu, rozpoczętej w 1519 r. i stopniowo wywierającej pewien wpływ na inne ośrodki południa Rzeszy, a być może także na Andreasa Bodensteina Karlstadta w Wittenberdze i Johannesa Hessa we Wrocławiu $^{22}$. O wyznaniu reformowanym jako o pewnej wspólnocie poglądów, obejmującej więcej ośrodków, zwykle mówi się dopiero od porozumienia między Genewą a Zurychem, zawartego w 1549 r. i zwanego ugodą zuryską (Consensus tigurinus). Sama w sobie ugoda nie oznaczała jeszcze stworzenia state Churches, a nawet w ocenie wielu historyków Kościoła była porażką, gdyż nie przezwyciężyła ostatecznie różnic dzielących Zurych i Genewę ani nie zyskała akceptacji Berna ${ }^{23}$. Warto także dodać, że „oficjalne uznanie” luteranizmu w Rzeszy nastąpiło dopiero w wyniku pokoju augsburskiego w 1555 r. Wyznanie reformowane kształtowało się później niż ewangelicko-augsburskie, według nieco innych zasad i w odmiennych warunkach polityczno-społecznych.

Wychodząc z powyższych obserwacji na temat stopniowego rozwoju wyznań i świadomości konfesyjnej, warto wrócić do określenia Czechowica „potrójnym apostatą” (s. 136), które padło już w przytoczonych na wstępie katolickich polemikach. Opiera się ono na wyobrażeniu, że teolog opuścił Kościół katolicki, a następnie luterański, by przyłączyć się do kalwinizmu i w końcu opowiedzieć po stronie Ecclesia minor, czyli antytrynitaryzmu. Izabela Winiarska-Górska ujęła to jeszcze radykalniej, pisząc, że „dla Marcina Czechowica jako brata polskiego (wcześniej protestanta) szczególnej wagi nabrało pytanie, czy dla wyznawców Pismo Święte jest księgą zrozumiałą i jasną" ${ }^{24}$ - czym wykluczyła antytrynitarzy z grona protestantów. Luszczynska, przywołując autobiograficzne

2002, s. 162-176; artykuł został przedrukowany w: idem, Transformationen. Studien zu den Wandlungsprozessen in Theologie und Frömmigkeit zwischen Spätmittelalter und Reformation, Tübingen 2015, s. 1-16.

${ }^{21}$ Por. B. Gordon, Calvin, New Haven 2009, s. 33-38.

${ }^{22}$ Zob. bardzo dobry przegląd w: Ph. Benedict, Christ's Churches Purely Reformed. A Social History of Calvinism, New Haven 2002, s. 9-76; ostatnio: A.N. Burnett, Karlstadt and the Origins of the Eucharistic Controversy. A Study in the Circulation of Ideas, Oxford 2011; eadem, Debating the Sacraments. Print and Authority in the Early Reformation, Oxford 2019.

${ }^{23}$ U. Gäbler, Consensus Tigurinus, w: Theologische Realenzyklopädie, t. 8, red. H.R. Balz et al., Berlin-New York 1981, s. 189-192.

24 I. Winiarska-Górska, Ideologia unitariańska, s. 305. 
świadectwa Czechowica, który podkreślał znaczenie opuszczania Kościoła katolickiego i przyłączenie „do samego tylko Słowa Bożego”, zwraca jednak uwagę, że pozostałe przemiany wyznaniowe nie znajdowały odzwierciedlenia w pismach teologa. Autorka nie potrafi wszelako tego przemilczenia przekonująco wyjaśnić. Tymczasem Czechowic, pracujący w latach trzydziestych i czterdziestych w Wielkopolsce, był zapewne szczerze przekonany, że służy prawdziwemu Kościołowi, a przenosząc się do Wilna, pod skrzydła Radziwiłła, mógł nie dostrzec większych różnic, bo działające już wówczas Kościoły ciągle nie miały jasno określonej tożsamości wyznaniowej. Nie chodzi tu o subiektywne przekonanie znane zapewne każdemu człowiekowi - że cechuje go niewzruszona stałość poglądów, a „święta racja” jest po jego stronie, lecz o obiektywny proces kształtowania się tożsamości wyznaniowej różnych grup konfesyjnych. Wydaje się zatem, że trudność wytłumaczenia rzekomego przemilczenia przez Czechowica jego wielokrotnych konwersji wynika z błędnej lub zbyt uproszczonej wizji przemian konfesyjnych pierwszych lat reformacji. Wyjaśnienia należy szukać nie w tekstach Czechowica, lecz w zarysowanej powyżej ewolucji stanowisk konfesyjnych i towarzyszącym jej wykształceniu się świadomości wyznaniowej. Procesy te przebiegały w Rzeczypospolitej nieco wolniej niż w Europie Zachodniej, choć zapewne nie diametralnie odmiennie.

Znaczenie owego dynamicznego obrazu przemian konfesyjnych w XVI w. jest szczególnie istotne w przypadku antytrynitarzy. W badaniach ostatnich lat są oni bowiem ukazywani - jak widać z powyższych cytatów - jako wspólnota skrajnie radykalna, właściwie niezasługująca na miano Kościoła protestanckiego, a może nawet chrześcijańskiego. W niektórych studiach bywają niepoprawnie idealizowani jako oświeceniowi deiści avant la lettre $e^{25}$, w innych zaś poddawani zabiegom egzotyzacji. Magdalena Hawrysz przypisała im nawet negację koncepcji duszy ${ }^{26}$. Idąc za utartą tradycją historiograficzną, Luszczynska zaś opisuje powstanie Ecclesia minor jako oderwanie od kalwinistycznej Ecclesia maior (s. 5, 10), innymi słowy - jako odłączenie radykalnej mniejszości od Kościoła

${ }^{25}$ Zob. oparte na powierzchownej lekturze historiografii eseje: J. Majmurek, Dlaczego bracia polscy?, w: Bracia polscy. Przewodnik Krytyki Politycznej, Warszawa 2012, s. 6-13; M. Pospiszyl, Arianie, oświecenie radykalne a sprawa polska, w: ibidem, s. 212-226. Por. poważną filozoficzną analizę przedstawioną w: S. Salatowsky, Die Philosophie der Sozinianer. Transformationen zwischen Renaissance-Aristotelismus und Frühaufklärung, Stuttgart 2015.

${ }^{26}$ M. Hawrysz, XVI-wieczny dyskurs polemiczny, s. 49 (,Ważnym zagadnieniem $\mathrm{w}$ analizowanych tu utworach jest także kwestionowanie boskości Chrystusa, istnienia duszy, a co za tym idzie - sprzeciw wobec czyśćca, mszy żałobnych [--] i innych obrzędów" - oczywiście żaden z teologów nie kwestionował istnienia duszy). 
kalwinistów. W istocie sytuacja w XVI w. wyglądała zgoła inaczej: decyzja większości kościołów małopolskich o opowiedzeniu się za kalwinizmem zapadła około 1556 r. Niemal równocześnie z nią rozpoczęły się dysputy na temat dogmatu Trójcy oraz chrystologii, sprowokowane przez wystąpienia Francesca Stancara i Piotra z Goniądza oraz powrót do Polski Giorgia Biandraty ${ }^{27}$. Stanowisko Piotra z Goniądza, którego po prostu synod obłożył klątwą, nakazując milczenie i wysyłając na egzamin do Wittenbergi, było mało istotne. Znacznie ważniejsze były szarże Stancara, oskarżającego wszystkich ortodoksyjnych teologów o powielanie błędów ariańskich. Kontrowersyjne wypowiedzi duchownego na temat usprawiedliwienia budziły dość powszechne zakłopotanie, a nawet zgorszenie. Reformowani duchowni na synodach małopolskich starali się możliwie zdecydowanie odrzucić poglądy Stancara, a zarazem odciąć się od formułowanych przez niego zarzutów arianizmu. W Kościele, który dopiero wkroczył w świat reformowanej teologii, brakowało wówczas odpowiednich myślicieli i autorytetów, którzy mogliby narzucić jedno stanowisko, co sprawiało, że synody lat 1559-1560 miały niezwykle burzliwy przebieg $^{28}$. Tym łatwiej dostrzeżono wówczas, po śmierci Łaskiego, właśnie w Biandracie teologa, który mógł przeciwstawić się poglądom Stancara. Mimo ostrzeżeń przed nieortodoksyjnymi poglądami włoskiego teologa, płynących z Genewy i Zurychu, a przedkładanych na synodach w latach 1560-1561, jego wpływ w środowisku małopolskim nieustannie rósł. W 1560 r. seniorzy zdecydowali o powierzeniu Biandracie godności superintendenta, co oznaczało de facto zapowiedź zerwania więzi z Genewą. U boku teologa stanął wówczas Francesco Lismanino. Obaj maskowali starannie własne poglądy, składając kolejne wyznania wiary, w których unikali nieortodoksyjnych stwierdzeń. Wówczas właśnie - na przełomie lata i jesieni 1561 r. - wyprawiono wspomnianą legację do Genewy, na czele której stanął Marcin Czechowic, opatrzony misją nakłonienia Kalwina do zawarcia zgody z Biandratą. Podczas następnych synodów małopolskich w latach 1562-1563 Kościoły małopolski i litewski przeszły na pozycje antytrynitarne. Innymi słowy, to nie „arianie” odłączyli się od kalwinistów, lecz Kościół reformowany w obawie przed zarzutem arianizmu przeszedł na pozycje antytrynitarne. Przeciw tej ewolucji protestował wytrwale Stanisław Sarnicki, który, współpracując z Jakubem Sylwiuszem, Pawłem Gilowskim i garstką duchownych, zdołał zgromadzić

27 Zob. wybór tekstów źródłowych z obszernym komentarzem w: Antitrinitarische Streitigkeiten. Die tritheistische Phase (1560-1568), red. I. Dingel, K. Daugirdas, Mainz 2013. Poniższe rozważania przedstawiono szerzej w: M. Ptaszyński, Reformacja w Polsce a dziedzictwo Erazma z Rotterdamu, Warszawa 2018, s. 604-620.

${ }^{28}$ Zob. L. Szczucki, op. cit., s. 24-25. 
wokół siebie świeckich patronów, zabiegając nieustannie o utrzymanie więzi z Genewą i Zurychem ${ }^{29}$. Dzięki poparciu teologów szwajcarskich stopniowo część Kościoła małopolskiego odzyskała ortodoksyjnie reformowane oblicze, a w Małopolsce powstały dwie organizacje kościelne, rywalizujące ze sobą niezwykle zawzięcie. Krótko mówiąc, Czechowic znalazł się we wspólnocie braci polskich nie w wyniku konwersji, lecz jedynie dzięki konsekwentnej obronie własnego stanowiska. Wśród braci polskich odgrywał kluczową rolę aż do przybycia Fausta Socyna, który zdołał przekonać większość antytrynitarzy do swoich poglądów $\mathrm{w}$ wielu miejscach drastycznie różnych od przekonań Czechowica $^{30}$.

$\mathrm{Na}$ zakończenie wypada jeszcze zwrócić uwagę na kilka rażących błędów rzeczowych. Autorka opatruje proces wykształcenia się Kościoła braci polskich krótką uwagą: „W 1564 r., wkrótce po odłączeniu [antytrynitarzy - M.P.] od kalwinistycznej alma mater, przedstawiciele tej ostatniej zabiegali u króla Zygmunta Augusta o wydanie edyktu przeciw arianom. W $1566 \mathrm{r}$. żądanie wygnania z kraju braci polskich zostało po raz pierwszy przedstawione w sejmie (izbie niższej parlamentu)" 31 . Jak zaś dalej twierdzi, pierwszy edykt przeciw braciom polskim przyjęto na sejmie lubelskim 1569 r. (s. 71), a ostatecznie w wyniku tych starć antytrynitarze zostali rzekomo wykluczeni z uchwalonej w 1573 r. Konfederacji Warszawskiej (s. 12). Cytowane zdania i przytoczone stwierdzenia są bardzo nieprecyzyjne lub błędne: sejm składał się z trzech izb poselskiej, senatu i króla. O podjęcie kroków prawnych i politycznych przeciw antytrynitarzom kalwiniści (czyli obóz Sarnickiego) zabiegali od samego początku, a areną starć stały się nie tylko synody, lecz także sejmy. Do najbardziej dramatycznych konfrontacji doszło na sejmie warszawskim 1563/1564 r. oraz sejmie piotrkowskim 1565 r. W 1563 r. kalwiniści zdołali wymóc na monarsze rozkaz spalenia dzieła Grzegorza Pawła z Brzezin, a król miał podobno wydać także polecenie konfiskaty innych pism antytrynitarskich. Na następnym sejmie w Parczewie, który zasłynął próbą wręczenia Zygmuntowi Augustowi postanowień soboru trydenckiego, król wystawił w sierpniu 1564 r. dwa edykty przeciw zbiegłym heretykom oraz „nowej sekcie”. Wydaje się nawet, że kancelarię

${ }^{29}$ Zob. bardzo obszerne omówienie w: W. Sławiński, Stanisław Sarnicki jako działacz reformacyjny, „Czasy Nowożytne” 18-19, 2005, s. 69-113 (cz. 1); 24, 2011, s. 11-35 (cz. 2).

30 Zob. L. Chmaj, Faust Socyn (1539-1604), Warszawa 1963; Z. Ogonowski, op. cit., s. 103-112; K. Daugirdas, op. cit., s. 63-164.

31 „In 1564, soon after they split from the Calvinist alma mater, the representatives of the latter lobbied King Sigismund August to issue edicts against the Arians. The postulate to expel the Polish Brethren from the country was first presented in Sejm (to lower house the parliament) in 1566", s. 11-12. 
królewską opuściły już wcześniej pierwsze mandaty przeciw antytrynitarzom. Jednym słowem, o edykty nie tylko zabiegano w 1564 r., lecz także je uzyskano. Kolejny edykt przygotowano na sejmie lubelskim 1566 r., ale zapewne pozostał on tylko projektem ${ }^{32}$. Autorka myli więc sejm $1566 \mathrm{r}$. z tym z 1569 r., gdyż źle interpretuje słowa Czechowica o „ostatecznym Lubelskim Seymie”, gdzie „ku temu, onego cichego y nigdy krwię cudzey nie pragnącego, sławney pamięci Króla Zygmunta Augusta przywiedli, że musiał usty swym dekret uczynić"33. Co ciekawe, wedle Czechowica akcje zorganizowali nie kalwiniści i luteranie (jak pisze Luszczynska, parafrazując ten ustęp na s. 71), lecz „Papieżnicy y Luterany y z innymi co się z nimi nie zgadzają" ${ }^{34}$. Podobnie jak wiele innych ustaw antyheretyckich także te mandaty nie były nigdy egzekwowane.

Wypada także dodać, że Konfederacja Warszawska przyjęta w 1573 r. oczywiście nie wykluczała żadnego Kościoła ani żadnej grupy wyznaniowej. Jak powszechnie wiadomo, enigmatyczny termin „dissidentes”, którym określili się sygnatariusze dokumentu, odnosił się zarówno do katolików, jak i protestantów. W konfederacji nie wspomniano jednak o żadnych Kościołach ani wyznaniach, definiując swobodę wyboru wyznania jako prerogatywę jednostek, choć wyłącznie w negatywnych kategoriach (jako zakaz prześladowań i ucisku). Tym samym żaden protestancki Kościół nie znalazł swojego uznania prawnego w konfederacji, ale również żadne wyznanie nie było z niej explicite wykluczone. Dopiero toczone w następnych dekadach walki o wyłożenie znaczenia dokumentu sprawiły, że antytrynitarzy uznano za wyłączonych z grona chrześcijan, a więc także za pozbawionych protekcji.

Podsumowując, należy podkreślić, że praca Magdaleny Luszczynskiej jest solidną rekonstrukcją wybranych wątków dotyczących stosunku do Żydów w dwóch traktatach polemicznych wiodącego teologa protestanckiego XVI w. Prócz tego nie oferuje jednak czytelnikowi wiele więcej: zarówno wykorzystanie bardzo bogatej literatury przedmiotu rozczarowuje, jak i umieszczenie sporu w kontekście historycznym należy uznać za bardzo powierzchowne. W stosunku do niezwykle rzetelnych i szczegółowych prac Konrada Górskiego o Grzegorzu Pawle, Lecha Szczuckiego o Czechowicu czy nawet syntetycznych ujęć Zbigniewa Ogonowskiego

${ }^{32}$ Zob. S. Bodniak, Sprawa wygnania arian wr. 1566, „Reformacja w Polsce” 5, 1928, s. 52-59; J. Tazbir, Walka z Braćmi Polskimi w dobie kontrreformacji, OiRP 1, 1956, s. 165-207; edycja projektu edyktu z 1566 r. w: Diariusz sejmu lubelskiego 1566 roku, oprac. I. Kaniewska, Wrocław 1980, s. 4-6.

${ }^{33}$ M. Czechowic, Odpis Jakoba Żyda z Bełżyc na Dyalogi Marcina Czechowica, na który zaś odpowieda Jakobowi Żydowi tenże Marcin Czechowic, Raków 1581, s. 47-48.

${ }^{34}$ Ibidem. 
monografia ta nie wnosi nowych ustaleń. Wąska baza źródłowa nie uprawnia do szerszych konkluzji, a przyjęte metody raczej nakazują umieścić pracę w kręgu literaturoznawstwa niż historiografii. Centralne pytanie pracy, czyli stosunek Czechowica do Żydów, okazuje się w świetle ustaleń Autorki kwestią marginalną: jednym ze sposobów, w jaki polemiści konfesyjni epoki nowożytnej zarysowywali swoje stanowisko i odcinali się od przeciwników. Aby zrozumieć sens i znaczenie tego określenia, warto odwołać się do kategorii świadomości wyznaniowej, rozumianej nie jako indywidualne kompetencje w zakresie teologii, lecz jako poczucie wspólnoty wytworzone przez podzielane podglądy i wartości, powielane praktyki oraz działanie instytucji.

\section{Streszczenie}

Monografia Magdaleny Luszczynskiej Politics of polemics. Marcin Czechowic on the Jews jest poświęcona dwóm dziełom jednego z najwybitniejszych polskich teologów protestanckich XVI w. Artykuł podejmuje niektóre wątki poruszane w pracy, umieszczając ją na tle badań nad Czechowicem oraz antytrynitarzami, a także stawiając pytanie o znaczenie języka polemik konfesyjnych dla historiografii oraz o rolę procesów kształtowania się świadomości wyznaniowej w XVI w. Wkład monografii do badań nad antytrynitaryzmem i Czechowicem oceniony jest jako niewielki, również ze względu na bardzo ubogą bazę źródłową pracy. Artykuł prezentuje tezę, wedle której najnowsze ustalenia badań nad reformacją i konfesjonalizacją wymagają również innego spojrzenia na kluczowe epizody biografii Czechowica oraz innych protestantów XVI w. Uznanie wspólnoty antytrynitarzy za równoprawny Kościół protestancki, do którego Czechowic przyłączył się w dość wczesnym momencie reformacji w Polsce i na Litwie, ukazuje w nowym świetle powtarzaną opinię o rzekomej potrójnej konwersji teologa.

\section{On the Culture of Religious Polemics and the Emergence of Religious Awareness. Some Remarks on the Margins of Magdalena Luszczynska's Politics of Polemics: Marcin Czechowic on the Jews}

Magdalena Luszczynska's monograph Politics of Polemics: Marcin Czechowic on the Jews is devoted to two writings by one of the most outstanding Polish Protestant theologians of the sixteenth century. The article takes up some of the topics discussed in the book, and sets it against the backdrop of research on Czechowic and anti-Trinitarians, posing the question about the importance of the language of confessional polemics for the historiography and the role of the processes of formation of religious awareness in the sixteenth century. The monograph's contribution 
to the studies of anti-Trinitarianism and Czechowic has been assessed as small, partly because of its very meagre source basis. The article puts forward the thesis that the most recent findings on the Reformation and confessionalization also require a different look at the crucial episodes in the lives of Czechowic and other sixteenth-century Protestants. The recognition of the anti-Trinitarian community as an equal Protestant Church, joined by Czechowic at an early stage of the Reformation in Poland and Lithuania, sheds new light on the prevailing opinion about the alleged triple conversion of the theologian.

\section{Bibliografia}

Antitrinitarische Streitigkeiten. Die tritheistische Phase (1560-1568), red. Irene Dingel, Kęstutis Daugirdas, Vandenhoeck \& Ruprecht, Mainz 2013.

Antytrynitaryzm w Pierwszej Rzeczypospolitej w kontekście europejskim. Źródła - rozwój - oddziaływanie, red. Michał Choptiany, Piotr Wilczek, Wydawnictwa UW, Warszawa 2017.

Benedict Philip, Christ's Churches Purely Reformed. A Social History of Calvinism, Yale University Press, New Haven 2002.

Beutel Albrecht, „Wir Lutherischen”. Zur Ausbildung eines konfessionellen Identitätsbewusstseins bei Martin Luther, „Zeitschrift für Theologie und Kirche” 110, 2013, s. $164-17$.

Bodniak Stanisław, Sprawa wygnania arian w r. 1566, „Reformacja w Polsce” 5, 1928, s. 52-59.

Bracia polscy. Przewodnik Krytyki Politycznej, Wydawnictwo Krytyki Politycznej, Warszawa 2012.

Burnett Amy Nelson, Debating the Sacraments. Print and Authority in the Early Reformation, Oxford University Press, Oxford 2019.

Burnett Amy Nelson, Karlstadt and the Origins of the Eucharistic Controversy. A Study in the Circulation of Ideas, Oxford University Press, Oxford 2011.

Chmaj Ludwik, Faust Socyn (1539-1604), Książka i Wiedza, Warszawa 1963.

Ciechan Paweł, Obraz jezuitów w Zwierściadłku panienek chrystyjańskich Marcina Czechowica, „Wschodni Rocznik Humanistyczny” 9, 2013, s. 31-41.

Czechowic Marcin, Rozmowy chrystyjańskie, oprac. Alina Linda, Maria Maciejewska, Lech Szczucki, Zdzisław Zawadzki, PWN, Warszawa-Łódź 1979.

Czechowic Marcin, Zwierściadłko panienek chrystyjańskich, oprac. Katarzyna Meller, Dariusz Chemperek, Neriton, Warszawa 2010.

Daugirdas Kęstutis, Die Anfänge des Sozinianismus. Genese und Eindringen des historischethischen Religionsmodells in den universitären Diskurs der Evangelischen in Europa, Vandenhoeck \& Ruprecht, Göttingen 2016.

Diariusz sejmu lubelskiego 1566 roku, oprac. Irena Kaniewska, Ossolineum, Wrocław 1980.

Dingel Irene, Wie lutherisch war die Wittenberger Reformation. Von konfessioneller Vielfalt zu theologischer Profilierung, w: Initia Reformationis. Wittenberg und die frühe Reformation, red. Irene Dingel, Armin Kohle. Stefan Rhein, Ernt-Joachim Waschke, Evangelische Verlagsanstalt, Leipzig 2017, s. 416-422. 
Gäbler Ulrich, Consensus Tigurinus, w: Theologische Realenzyklopädie, t. 8, red. Horst R. Balz et al., de Gruyter, Berlin-New York 1981, s. 189-192.

Gordon Bruce, Calvin, Yale University Press, New Haven 2009.

Gregory Brad, Niezamierzona reformacja. Od rewolucji religijnej do świeckiego społeczeństwa, [w druku].

Hawrysz Magdalena, XVI-wieczny dyskurs polemiczny w świetle pism Grzegorza Pawła z Brzezin, „Poznańskie Studia Polonistyczne. Seria Językoznawcza” 25 (45), 2018, s. $45-59$.

Hawrysz Magdalena, Polemiczna twórczość Marcina Czechowica w perspektywie genologii lingwistycznej, Oficyna Wydawnicza Uniwersytetu Zielonogórskiego, Zielona Góra 2012.

Jasnowski Józef, Mikołaj Czarny Radziwiłt (1515-1565). Kanclerz i marszałek ziemski Wielkiego Księstwa Litewskiego, wojewoda wileński, nakł. Towarzystwa Naukowego Warszawskiego, Warszawa 1939.

Kolarzowski Jerzy J., Idea praw jednostki w pismach braci polskich. U narodzin nowożytnej koncepcji praw człowieka, Wydawnictwa UW, Warszawa 2009.

Kot Stanisław, Czechowic Marcin, PSB, t. 4, Kraków 1938, s. 306-309.

Kowalska Halina, Działalność reformatorska Jana Łaskiego w Polsce 1556-1560, Neriton, Warszawa 1999.

Leppin Volker, Transformationen. Studien zu den Wandlungsprozessen in Theologie und Frömmigkeit zwischen Spätmittelalter und Reformation, Mohr Siebeck, Tübingen 2015.

Leppin Volker, Wie reformatorisch war die Reformation? „Zeitschrift für Theologie und Kirche" 99, 2002, s. 162-176.

Luszczynska Magdalena, Politics of polemics: Marcin Czechowic on the Jews, De Gruyter Oldenbourg, Berlin-Boston 2018.

Łaszcz Marcin, Okulary na Zwierciadlo nabozenstwa chrześcianskiego w Polszcze. Począwszy od przystania Polakow na wiarę Chrześciańska, aż do teraźnieyszego Roku 1594, Wilno 1594.

Majmurek Jakub, Dlaczego bracia polscy?, w: Bracia polscy. Przewodnik Krytyki Politycznej, Wydawnictwo Krytyki Politycznej, Warszawa 2012, s. 6-13.

Meller Katarzyna, Słowa jak ziarna. Reformacyjne idee, książki, spory, Wydawnictwo Naukowe UAM, Poznań 2012.

Ogonowski Zbigniew, Socynianizm. Dzieje, poglądy, oddziaływanie, IHN PAN, Aspra-Jr, Warszawa 2015.

Pietkiewicz Rajmund, Biblia Polonorum. Historia Biblii w języku polskim, t. 1: Od początku do 1638 roku, Pallottinum, Poznań 2016.

Pietkiewicz Rajmund, Polskie antytrynitarskie przekłady Biblii w dialogu Pierwszej Rzeczypospolitej ze wschodnia i zachodnia Europa, w: Antytrynitaryzm w Pierwszej Rzeczypospolitej w kontekście europejskim. Źródła - rozwój - oddziaływanie, red. Michał Choptiany, Piotr Wilczek, Wydawnictwa UW, Warszawa 2017, s. 262-286.

Pospiszyl Michał, Arianie, oświecenie radykalne a sprawa polska, w: Bracia polscy. Przewodnik Krytyki Politycznej, Wydawnictwo Krytyki Politycznej, Warszawa 2012, s. 212-226.

Ptaszyński Maciej, Reformacja w Polsce a dziedzictwo Erazma z Rotterdamu, Wydawnictwa UW, Warszawa 2018. 
Ptaszyński Maciej, rec.: Antytrynitaryzm w Pierwszej Rzeczypospolitej w kontekście europejskim. Źródła - rozwój - oddziaływanie, red. Michał Choptiany, Piotr Wilczek, Warszawa 2017, „Odrodzenie i Reformacja w Polsce” 62, 2018, s. 230-234.

Ptaszyński Maciej, rec.: J.J. Kolarzowski, Idea praw jednostki w pismach braci polskich. U narodzin nowożytnej koncepcji praw człowieka, Warszawa 2009, „Odrodzenie i Reformacja w Polsce" 56, 2012, s. 261-272.

Salatowsky Sascha, Die Philosophie der Sozinianer. Transformationen zwischen Renaissance-Aristotelismus und Frühaufklärung, Frommann-Holzboog, Stuttgart 2015.

Sławiński Wojciech, Stanisław Sarnicki jako działacz reformacyjny, „Czasy Nowożytne” 18-19, 2005, s. 69-113 (cz. 1); 24, 2011, s. 11-35 (cz. 2).

Sojka Jerzy, Luter jako arcyheretyk i rewolucjonista - powrót XVI-wiecznej antyreformacyjnej polemiki w polskiej debacie w roku jubileuszu 500 lat reformacji, w: Marcin Luter 1517-2017, red. Krzysztof Obremski, Wydawnictwo Naukowe UMK, Toruń 2018, s. 113-134.

Szczucki Lech, Marcin Czechowic (1532-1613). Studium z dziejów antytrynitaryzmu polskiego XVI wieku, PWN, Warszawa 1964.

Tazbir Janusz, Walka z Braćmi Polskimi $w$ dobie kontrreformacji, „Odrodzenie i Reformacja w Polsce" 1, 1956, s. 165-207.

Warszawska szkoła historii idei. Tożsamość, tradycja, obecność, red. Paweł Grad, Wydawnictwo IFiS PAN, Warszawa 2014.

Wilczek Piotr, Polonia reformata. Essays on the Polish reformation(s), Vandenhoeck \& Ruprecht, Göttingen 2016.

Wilczek Piotr, Wyobraźnia. Polemiki Marcina Łaszcza z Marcinem Czechowicem, w: idem, Dyskurs - przekład - interpretacja. Literatura staropolska i jej trwanie we współczesnej kulturze, Gnome, Katowice 2001, s. 115-127.

Winiarska-Górska Izabela, Ideologia unitariańska a strategie translatorskie i styl przekładu Nowego Testamentu Marcina Czechowica (1577), „Poznańskie Studia Polonistyczne. Seria Językoznawcza” 25 (45), 2018, s. 277-313.

Winiarska-Górska Izabela, Szesnastowieczne przekłady Pisma Świętego na język polski (1551-1599) jako gatunek nowożytnej książki formacyjnej, Wydział Polonistyki Uniwersytetu Warszawskiego, Warszawa 2017.

Żukowski Jacek, Sąd nad arianami w kieleckim Pałacu Biskupów Krakowskich, Muzeum Narodowe, Kielce 2018.

Biogram: dr hab. Maciej Ptaszyński - wykładowca na Wydziale Historii Uniwersytetu Warszawskiego. Zainteresowania badawcze i publikacje dotyczą dziejów reformacji w Królestwie Polskim i w Rzeszy, historii stosunków wyznaniowych w XVII-XVIII w. oraz teorii politycznych epoki nowożytnej; kontakt: m.ptaszynski@uw.edu.pl.

Author: Maciej Ptaszyński, Dr hab. - lecturer at the Institute of History of the University of Warsaw. His research interests and publications focus on the history of Reformation in the Kingdom of Poland and the German Empire, history of denominational relations in the seventeenth and eighteenth centuries, and political theories of the early modern era. Contact: m.ptaszynski@uw.edu.pl 